\title{
Sedation at Endoscopic Units in Galicia: results of the "Sociedad Gallega de Patología Digestiva" inquiry
}

\author{
J. Cubiella Fernández, A. Lancho Seco, A. Echarri Piudo, J. L. Ulla Rocha, J. Fernández Seara on behalf \\ of Sociedad Gallega de Patología Digestiva
}

Service of Digestive Diseases. Complexo Hospitalario. Ourense, Spain

\begin{abstract}
Aim: to evaluate the human and material resources available for sedation, and the usual manner of handling them at endoscopic units in Galicia.

Methods: a prospective and descriptive study based on the performance, distribution, and analysis of a clinical practice inquiry. We requested information about endoscopies performed, available means for sedation, sedation monitoring, and level of sedation used in each procedure.

Results: our inquiry was answered by twenty endoscopic units (thirteen were in public hospitals, and eleven performed complex procedures). Of these units, $80 \%$ had a pulse oximeter, $42 \%$ had continuous electrocardiography, $40 \%$ had a defibrillator, and $45 \%$ had a recovery area. The drug most commonly used in gastroscopies was midazolam (76\%), and the combination midazolammeperidine was most frequent in both colonoscopies $(72 \%)$ and ERCPs (60\%). An anesthesiologist was usually available for certain procedures in $15 \%$ of units, and as an exception in 65\%. Of those inquired, 35\% wished to have a full-time anesthesiologist in the unit, $25 \%$ wished to have an anesthetist only for certain procedures, and $35 \%$ on an exceptional basis. Finally, endoscopists considered that $83 \%$ of therapeutical gastroscopies, $87 \%$ of therapeutical colonoscopies, 98\% of ERCPs, 95\% of enteroscopies, and $98 \%$ of echoendoscopies deserved sedation.

Conclusions: although endoscopists consider that endoscopic procedures should benefit from sedation in a high proportion, the available resources to safely monitor patients are inadequate in some units.
\end{abstract}

Key words: Endoscopy, gastrointestinal. Proffesional practice. Conscious sedation. Sedatives. Drug. Complications.

Recibido: 03-03-04.

Aceptado: 15-06-04.

Correspondencia: Joaquín Cubiella Fernández. Servicio de Aparato Digestivo. Complexo Hospitalario de Ourense. Rua Ramón Puga, 52-54. 32003 Ourense. Telf.: 988385715 - Fax: 988385 518. e-mail: joaquin.cubiella.fernandez@sergas.es
Cubiella Fernández J, Lancho Seco A, Echarri Piudo A, Ulla Rocha JL, Fernández Seara J on behalf of Sociedad Gallega de Patología Digestiva. Sedation at Endoscopic Units in Galicia: results of the "Sociedad Gallega de Patología Digestiva" inquiry. Rev Esp Enferm Dig 2005; 97: 24-37.

\section{INTRODUCTION}

Sedation in digestive endoscopy is an important part of everyday's clinical practice. Depending on the country, routine use ranges from 44 to $72 \%$ (1). Even though it increases tolerance in some explorations (2), sedation is also related to an increased morbidity rate, especially from cardiopulmonary complications (3-6). These complications arise in relation to age and associated conditions $(4,6)$. Therefore, not only should endoscopists use drugs, but they also should have available the necessary means and knowledge to monitor the patient during the procedure. Although consensus documents and recently published clinical guidelines detail the minimum requirements for correct sedation and monitoring (3-5), our inquiry on sedation at endoscopy units shows great variability both in sedation type and the available means for patient monitoring (7-9).

Sociedad Gallega de Patología Digestiva (SGPD) is the gastroenterologists' representative society in Galicia. Following a program introduced for a better knowledge of clinical practice in the Galician region, an evaluation of sedation patterns at endoscopy units was undertaken that took examination type into account. The aim of this study was to find out the available means, regular method of sedation, and sedation method desired by endocopists at endoscopy units in Galicia. 


\section{MATERIAL AND METHODS}

\section{Investigation design}

A prospective and descriptive research on the performance, distribution, and analysis of an inquiry on clinical practice.

\section{Questionnaire elaboration}

The inquiry was set by the authors on the basis of a review of clinical guidelines, consensus documents, and sedation inquiries published $(2,4,6-8)$. Once a consensus was reached, the inquiry was submitted to the SGPD direction board. The direction board approved the questionnaire and its sending to regional endoscopy units. A copy of this questionnaire is included in table I.

Table I. Questionnaire on sedation designed by SGPD and mailed to endoscopy units within hospitals in the Galician region. Participating specialists were requested to provide information on the volume and type of endoscopic studies carried out, their available material and human resources, the usual way of sedation, their background on severe associated complications, their sources of knowledge regarding sedation, and the desired level of sedation in each exploration

\section{SOCIEDAD GALLEGA DE PATOLOGÍA DIGESTIVA. QUESTIONNAIRE ON SEDATION}

TYPE OF EXPLORATIONS PERFORMED IN YOUR UNIT

What is the approximate number of endoscopic explorations performed in your unit every year?

- Diagnostic gastroscopies:

Therapeutic gastroscopies:

- Sigmoidoscopies:

Diagnostic colonoscopies:

- Therapeutic colonoscopies:

ERCPs:

- Enteroscopies:

Echoendoscopies:

- Laparoscopies:

What is the aproximate rate of explorations with sedation in your unit?: A: 0-25\%, B: 25-50\%, C: 50-75\%, D: 75-100\%.

- Diagnostic gastroscopies

- Therapeutic gastroscopies

- Sigmoidoscopies

- Diagnostic colonoscopies

- Therapeutic colonoscopies

- ERCPs

- Enteroscopies

- Echoendoscopies

$\begin{array}{llll}A & B & C & D \\ A & B & C & D \\ A & B & C & D \\ A & B & C & D \\ A & B & C & D \\ A & B & C & D \\ A & B & C & D \\ A & B & C & D\end{array}$

MATERIAL AND HUMAN RESOURCES AVAILABLE:

What material resources are available to sedate patients in your endoscopy unit?

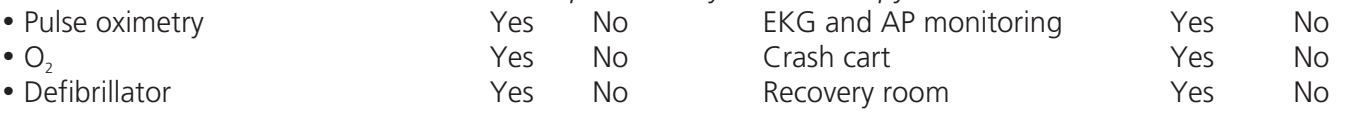

What drugs are available?

- Oral/endovenous diazepam Yes No Oral/endovenous midazolam Yes No

- Endovenous meperidine Yes No Propofol $\quad$ Yes No

- Droperidol Yes No Anexate $\quad$ Yes No

- Atropine Yes No Other. Specify:

Which drugs are most widely used for sedation and analgesia?

- Diagnostic gastroscopies:

- Sigmoidoscopies:

- Therapeutic colonoscopies:

Therapeutic gastroscopies:

Diagnostic colonoscopies:

- Enteroscopies:

ERCPs:

Echoendoscopies:

Is there an anesthetist in your unit?

- Always available in the unit.

- Only for certain explorations (ERCP,...), but on a regular basis.

- Available in the unit immediately when called, but that rarely happens.

- Not immediately available in the unit: scheduling is needed.

- Not available in the unit: endoscopies must be performed in operation theaters. 
Table I (continuation)

If you have an anesthetist in the unit, is he or she usually the same, or changes frequently?

If you have a recovery room:

- How many beds are available?

- Who controls patients?

Which resources are available in the recovery room?

- Pulse oximetry Yes No

- $\mathrm{O}_{2} \quad$ Yes No

EKG and AP monitoring Yes No

- Defibrillator

Yes No

Crash cart

If you do not have an anesthetist, who controls sedation?

- The endoscopist Yes No The nurse Yes No

In case the endoscopist is in charge of sedation,

-Where was he/she educated on conscious sedation?

Academic courses

Anesthesia department

In a practical way

Other

During residence

- Do you remember any severe adverse events related to sedation in your unit? No

Yes. Which ones?

Would you like an anesthetist in your unit?

- Yes, full time for all explorations

Only for ERCP

- Only for exceptional cases

Never

What level of sedation do you think necessary for each exploration (in percentage, so that the sum is 100\%)?

\begin{tabular}{|l|l|l|l|}
\hline & No sedation & Conscious sedation & Deep sedation \\
\hline Diagnostic gastroscopies & & & \\
\hline Therapeutic gastroscopies & & & \\
\hline Sigmoidoscopies & & & \\
\hline Diagnostic colonoscopies & & & \\
\hline Therapeutic colonoscopies & & & \\
\hline ERCPs & & & \\
\hline Enteroscopies & & & \\
\hline Echoendoscopies & & & \\
\hline
\end{tabular}

\section{Sedation definitions}

Definitions used were already described in the literature (3-5). Thus, conscious sedation was defined as a technique in which the administration of a drug induces a depression of the central nervous system that allows exploration, and during which the verbal contact with the patient is maintained and both the breathing and cardiovascular functions are stable. In contrast, deep sedation was defined as a type of sedation in which the patient has no responses to verbal or painful stimuli, and may not keep an open airway, thus often requiring breathing support.

\section{Inquiry submission}

Searching through Catálogo de Hospitais Galicia 2000, published by Secretaría General del Servicio Gallego de Salud (SERGAS), 29 endoscopy units were identified in hospitals throughout the Galician region. Of these units, 17 were in public hospitals (14 belonged to the SERGAS network, two to public foundations, and one to a military hospital), two were in state-assisted private hospitals, and 10 in private hospitals. Questionnaires were sent by mail to the specialist in charge of each unit in March 2003. Two months later, units that had not answered the inquiry were contacted by telephone, and the inquiry was mailed once again. 


\section{Statistical analysis}

A descriptive analysis of answers was performed. We performed a univariate analysis in order to detect differences between private and public hospitals and between those that made highly complex explorations (ERCPs, enteroscopies, echoendoscopies) and those that did not. Fisher's exact test was used for qualitative variables, and Mann-Whitney's test for quantitative variables. Differences were considered statistically significant when $\mathrm{p}<$ 0.05 . The statistical analysis was performed using the SPSS 10.0 statistical package.

\section{RESULTS}

\section{Unit characteristics}

The questionnaire was answered by 20 endoscopy units. Thirteen of the responding units were public (11 belonged to the SERGAS network, one was a foundation, and one was a military hospital) and seven were private (two state-assisted private hospitals). Of these 20 units, 11 performed complex explorations (ERCP 11, enteroscopies 6, echoendoscopies 3). The volume and type of explorations is shown in table II.

\section{Available materials and human resources}

The material resources and drugs available for sedation in these endoscopy units are listed in table III. A univariate analysis has only identified significant statistical differences $(p=0.026)$ in pulse oximetry availability between units practicing complex explorations (11/11) and units not practicing complex explorations (5/9). On the other hand, the median of beds in recovery rooms was 2.5 (range 1-6); eight of the recovery rooms had pulse oximetry and oxygen, four had blood pressure and electrocardiography monitoring, six had a crash cart, and five had a defibrillator. Regarding anesthetists availability, none of the units had a permanent anesthetist. Fifteen percent of units had an anesthetist only for complex explorations, but on a common basis. Thirty percent of

Table II. Types of exploration carried out by the responding endoscopy units, and volume of endoscopies expressed as median, minimum and maximum values

\begin{tabular}{|c|c|c|c|c|}
\hline & No. of centers & Median explorations & Minimum & Maximum \\
\hline Gastroscopies (total) & 19 & 1000 & 77 & 6000 \\
\hline Gastroscopies (therapeutic) & 17 & 95 & 2 & 1500 \\
\hline Colonoscopies (total) & 20 & 862 & 80 & 4300 \\
\hline Colonoscopies (therapeutic) & 18 & 187.5 & 6 & 1967 \\
\hline ERCPS & 11 & 106 & 2 & 450 \\
\hline Enteroscopies & 6 & 20 & 3 & 100 \\
\hline Echoendoscopies & 3 & 170 & 137 & 260 \\
\hline Total & 20 & 1885 & 80 & 11110 \\
\hline
\end{tabular}

Table III. Material resources and drugs available for sedation in units

\begin{tabular}{|c|c|c|c|c|c|}
\hline & \multirow[b]{2}{*}{ All } & \multicolumn{2}{|c|}{ Hospital ownership } & \multicolumn{2}{|c|}{$\begin{array}{l}\text { Units that perform } \\
\text { complex explorations }\end{array}$} \\
\hline & & Public & Private & Yes & No \\
\hline $\begin{array}{l}\text { Oxygen } \\
\text { Pulse oximetry } \\
\text { EKG and A.P. monitoring } \\
\text { Crash cart } \\
\text { Defibrillator } \\
\text { Recovery room }\end{array}$ & $\begin{array}{c}19 / 20(95 \%) \\
16 / 20(80 \%) \\
8 / 19(42 \%) \\
16 / 20(80 \%) \\
8 / 20(40 \%) \\
9 / 20(45 \%)\end{array}$ & $\begin{array}{l}13 / 13(100 \%) \\
11 / 13(84.6 \%) \\
7 / 12(58.3 \%) \\
12 / 13(92.3 \%) \\
6 / 13(46.2 \%) \\
5 / 13(38.5 \%)\end{array}$ & $\begin{array}{l}6 / 7(85.7 \%) \\
5 / 7(71.4 \%) \\
1 / 7(14.3 \%) \\
4 / 7(57.1 \%) \\
2 / 7(28.6 \%) \\
4 / 7(57.1 \%)\end{array}$ & $\begin{array}{c}11 / 11(100 \%) \\
11 / 11(100 \%)^{*} \\
5 / 11(45.5 \%) \\
10 / 11(90.9 \%) \\
4 / 11(36.4 \%) \\
7 / 11(63.6 \%)\end{array}$ & $\begin{array}{l}8 / 9(88.9 \%) \\
5 / 9(55.6 \%)^{\star} \\
3 / 8(37.5 \%) \\
6 / 9(66.7 \%) \\
4 / 9(44.4 \%) \\
2 / 9(22.2 \%)\end{array}$ \\
\hline \multicolumn{6}{|l|}{ Drugs } \\
\hline $\begin{array}{l}\text { Midazolam } \\
\text { Flumazenil } \\
\text { Atropine } \\
\text { Meperidine } \\
\text { Diazepam } \\
\text { Propofol } \\
\text { Droperidol }\end{array}$ & $\begin{array}{c}19 / 20(95 \%) \\
18 / 20(90 \%) \\
18 / 20(90 \%) \\
18 / 20(90 \%) \\
15 / 20(75 \%) \\
6 / 20(30 \%) \\
4 / 20(20 \%)\end{array}$ & $\begin{array}{c}13 / 13(100 \%) \\
12 / 13(92.3 \%) \\
12 / 13(92.3 \%) \\
12 / 13(92.3 \%) \\
10 / 13(76.9 \%) \\
3 / 13(23.1 \%) \\
4 / 13(30.8 \%)\end{array}$ & $\begin{array}{c}6 / 7(85.7 \%) \\
6 / 7(85.7 \%) \\
6 / 7(85.7 \%) \\
6 / 7(85.7 \%) \\
5 / 7(71.4 \%) \\
3 / 7(42.9 \%) \\
0 / 7(0 \%)\end{array}$ & $\begin{array}{c}11 / 11(100 \%) \\
11 / 11(100 \%) \\
10 / 11(90.9 \%) \\
10 / 11(90.9 \%) \\
8 / 11(72.7 \%) \\
2 / 11(18.2 \%) \\
4 / 11(36.4 \%)\end{array}$ & $\begin{array}{c}8 / 9(88.9 \%) \\
7 / 9(77.8 \%) \\
8 / 9(88.9 \%) \\
8 / 9(88.9 \%) \\
7 / 9(77.8 \%) \\
4 / 9(44.4 \%) \\
0 / 9(0 \%)\end{array}$ \\
\hline
\end{tabular}

Results are broken down considering hospital ownership and the practice of highly complex explorations in units. Results are shown as absolute numbers and rates. Statistically significant differences are marked with an asterisk 
units had an anesthetist immediately when required, but that rarely happened. Forty-five percent of the units could not have an anesthetist immediately, his/her presence having to be scheduled beforehand. Finally, $30 \%$ of units never had an anesthetist, and had to use an operation theater for explorations.

\section{Common method of sedation}

On the one hand, the number of units performing more than $50 \%$ of diagnostic and therapeutic gastroscopies with sedation was $7 / 11$ and $11 / 18$, respectively; of diagnostic and therapeutic colonoscopies was 11/20 and 14/19, respectively; of ERCPs was 11/11; of enteroscopies was $5 / 6$, and of echoendoscopies was $2 / 3$. On the other hand, even though midazolan was the most used drug for sedation in gastroscopies, both diagnostic and therapeutic, and enteroscopies, a combination of midazolam and meperidine was the most common sedation method used in colonoscopies and ERCPs (Fig. 1). In the absence of an anesthetist, sedation was controlled in $44 \%$ of units by the endoscopist, and in $55 \%$ by the endoscopist together with a nurse. At the recovery room, patients were controlled by a nurse in $55.6 \%$ of units, by the endoscopist in $11.1 \%$, and by both in $22.2 \%$. Finally, in $11.1 \%$ of endoscopy units patients were not controlled at all. No statistically significant differences were found in the previously mentioned variables.

The knowledge for manipulating sedation drugs and their monitoring was acquired through practical experience in $31 \%$ of cases, during residence in $68 \%$, from academic courses in $12 \%$, and in other ways in $12 \%$ of cases. Besides, $33 \%$ of units remembered having had some severe difficulties associated with sedation: breathing de-

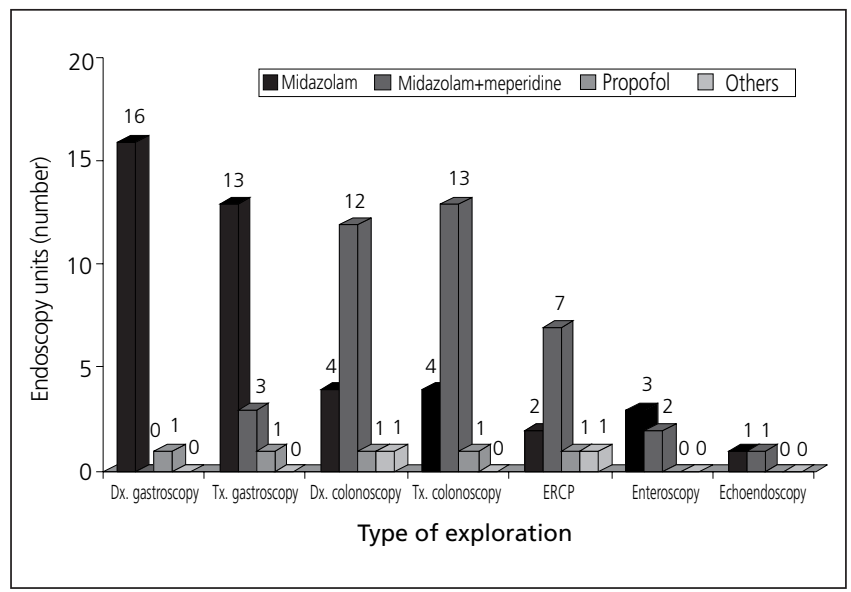

Fig. 1.- Types of drugs most frequently used in each unit for sedation considering the kind of endoscopic exploration. Dx: diagnostic; Tx: therapeutic.

Tipo de fármacos utilizados más habitualmente en cada unidad para la sedación en función de la exploración endoscópica. Dx: diagnóstica; Tx: terapéutica. pression in two of the units, respiratory arrest in two of the units, and generalized seizures in one of the units.

\section{Desirable sedation level}

When questioned about the need for an anesthetist within the unit, $35 \%$ of units would like a full time anesthetist for explorations, $35 \%$ only under rare circumstances, and finally $35 \%$ would not desire one. Finally, specialists considered that some level of sedation was required, as expressed in mean \pm standard deviation (SD), in $53.5 \%(\mathrm{SD} \pm 30.9 \%)$ of diagnostic gastroscopies, in $83 \%$ (SD $\pm 16.1 \%$ ) of therapeutic gastroscopies, in $80.3 \%$ (SD $\pm 19 \%$ ) of diagnostic colonoscopies, in $87 \%$ $(\mathrm{SD} \pm 17.1 \%)$ of therapeutic colonoscopies, in $98 \%$ (SD $\pm 6.9 \%)$ of ERCPs, in $95 \%(\mathrm{SD} \pm 14.1 \%)$ of enteroscopies, and in $98 \%$ (SD $\pm 4.5 \%$ ) of echoendoscopies. The breakdown of these results considering type of sedation (no sedation, conscious sedation, deep sedation), is shown in figure 2 . No statistically significant differences were found in relation with the type of hospital or the complexity of explorations carried out by units.

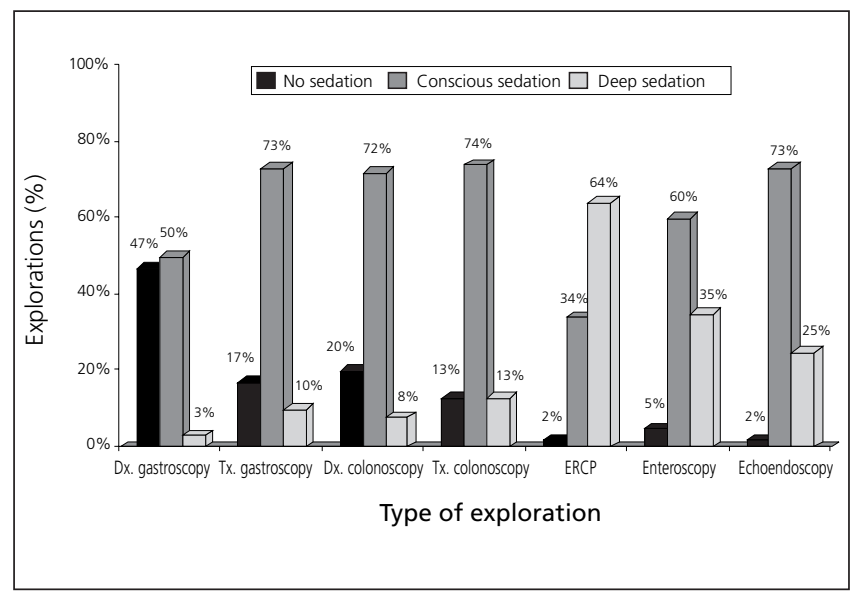

Fig. 2.- Rate of explorations according to the level of sedation considered necessary for each type of endoscopy. Results are expressed as mean values.

Porcentaje de exploraciones en función del grado de sedación que se considera necesario en cada tipo de endoscopia. Se expresan los resultados en media.

\section{DISCUSSION}

The SGPD inquiry shows that although Galician endoscopy units considered that most patients should be sedated, this is not their usual clinical practice for certain explorations. Several inquiries have evaluated sedation in endoscopy units throughout Europe (7-10). Recently, the result of an inquiry on sedation habits in Catalonia, Spain, has been published as an abstract (11). The methodology used in previously published studies is diverse: anonymous 
inquiries $(8,11)$, database retrospective revisions (10), and prospective assessment of sedation type $(7,9)$. Our main objective in developing this questionnaire was to know the available resources and the subjective assessment by endoscopists on sedation needs. Several aspects of clinical practice such as type of sedation for each exploration, drugs used, and number of complications need a prospective study to be correctly evaluated. Nevertheless, the results of this inquiry reflect common clinical practice and requirements to sedate, as evaluated by Galician professionals regardless of center ownership, number of endoscopies performed, and complexity.

Although several clinical guidelines and consensus documents have been published with recommendations on the necessary resources to sedate and type of sedation desired for each exploration (3-5), published inquiries show differences between these recommendations and clinical practice. On the other hand, besides a discussion on the need and level of sedation desired for each exploration, it is clear that some minimum resources and basic knowledge are required for a safe management of sedation during endoscopy. In fact, sedation is responsible for between 30 and $50 \%$ of human and material costs in diagnostic gastroscopies (12).

Monitorization during the endoscopic procedure allows to detect early evidence of complications such as changes in respiratory function, heart rate, blood pressure, and cardiac electric activity. Although monitorization with electronic devices improves patient assessment, it should not replace clinical control (5). A pulse oximetry may improve control of the respiratory function in patients under sedation and analgesia $(13,14)$. Besides, the administration of oxygen before and during endoscopy reduces desaturation (12). That way monitorization with pulse oximetry as well as oxygen administration is recommended during all endoscopies with sedation (5). In our inquiry, although most units had oxygen available, $20 \%$ had no pulse oximeter. This information is in accordance with the inquiry performed by Fasoli et al. on quality parameters in colonoscopies in Northern Italy. In this inquiry, we saw that although $63.9 \%$ of endoscopies were performed with sedation, only $44.2 \%$ of patients were monitored using pulse oximetry (9). When it comes to electrocardiographic monitoring, it is recommended only in patients with cardiorespiratory conditions, of advanced age, or in prolonged procedures (5). In Galicia, it was only available in $42 \%$ of units. We did not ask for any information on other technologies in current evaluation, such as capnography or biespectral monitoring (5). On the other hand, endoscopy units should have the material resources needed to immediately rescue a patient should complications arise (4). In our inquiry, we show that serious deficiencies exist especially regarding lack of defibrillators in most units. Furthermore, we would like to emphasize that only $45 \%$ of the inquired units had a recovery room. Therefore, recovery after sedation was carried out at endoscopy rooms in most cases.
There are several controversies on the usefulness of sedation during endoscopic procedures, especially in gastroscopies and diagnostic colonoscopies. Although both procedures may be performed without sedation in most patients $(15,16)$, they are well tolerated in only $59 \%$ of gastroscopies (15) and in $61 \%$ of diagnostic colonoscopies (17). There are few randomized studies evaluating the usefulness of sedation in these procedures (1820). In those studies, the improvement in tolerance after premedication was scarce. Factors such as advanced age and lower pharyngeal sensitivity in gastroscopies (15), and sex or a previous enteric resection in colonoscopy (16) are associated with improved tolerance of the procedure without sedation. Our inquiry was not designed to evaluate the rate of procedures performed with sedation. Thus, results are not comparable to those published in the literature. Nevertheless, we have to point out that 63.2 and $45 \%$ of units use sedation in less than $50 \%$ of gastroscopies and diagnostic colonoscopies, respectively. On the other hand, the rate of units not using sedation in more than $50 \%$ of therapeutic or complex procedures lowers widely. However, units answered that gastroscopies and diagnostic colonoscopies should be performed with conscious sedation in 50 and $72 \%$ of cases, respectively, and with deep sedation in 3 and $8 \%$ of cases, respectively. This rate disagrees with the current clinical practice in our units, probably in relation to the deficient monitoring resources and increased exploration time due to sedation. In a study recently carried out by Campo et al. in Catalonia, Spain, $17 \%$ of gastroscopies, $61 \%$ of colonoscopies, and $100 \%$ of ERCPs were performed with some level of sedation (11). These results are comparable to those of our study.

Both clinical guidelines and consensus documents recommend the use of benzodiazepines, especially midazolam, for conscious sedation during endoscopy $(2,3,5)$. Although data on the benefit of the combined use of benzodiazepines and opioids such as meperidine are contradictory, their use is widespread (7). In our inquiry, while monotherapy with midazolam was the preferred treatment for sedation during gastroscopies and enteroscopies, the combination of midazolam and meperidine was a favorite for colonoscopies and ERCPs. On the other hand, in order to perform a safe sedation, drugs able to rapidly revert effects on the central nervous system are needed. In our inquiry, endoscopy units had benzodiazepine antagonists in a high rate.

In some complex and long procedures, patients benefit from sedation with drugs such as propofol to induce deep sedation (4). Deep sedation has been shown to be superior to conscious sedation in complex endoscopies such as ERCPs. However, deep sedation has little benefit over conscious sedation during routine endoscopy (19). This kind of sedation requires intensive monitoring by a qualified staff. In case of associated increased risk, it must be controlled by an anesthetist (5). In our inquiry, propofol was used in $6 \%$ of gastroscopies and therapeutic colono- 
scopies, and in $10 \%$ of ERCPs. On the other hand, although anesthetists are usually available to monitor and control sedation in endoscopy units, none of the units explored had an anesthetist permanently. In fact, $35 \%$ of the inquired answered that they wished they could have an anesthetist always in the unit. In the results published as an abstract by Campo et al., an anesthetist was responsible for sedation in $7 \%$ of gastroscopies, $25 \%$ of colonoscopies, and $38 \%$ or ERCPs (11). These results suggest sedation patterns similar to those seen in Galicia.

The practitioner in charge of initiating sedation must have specific training allowing him or her to safely handle the patient during the procedure. He must know the doses and adverse effects, the ways to revert effects, and how to handle monitoring resources. In addition, he or she must be able to safely perform cardiorespiratory resuscitation maneuvers. In our inquiry, most endoscopists had picked their knowledge up during residence or through practice. Practitioners having gone through specific academic courses on sedation techniques were rare. So, endoscopists should have specific training on sedation techniques during residence, and this knowledge should be updated frequently.

To sum it all up, although endoscopy units in Galicia are well-equipped regarding drugs, there are marked deficiencies in monitoring equipment. Besides, the rate of units that do sedate is usually low. However, endoscopists consider that patients should be sedated during endoscopy more often that currently performed. A prospective national study to evaluate the resources available for sedation and the common clinical practice is required. The minimum conditions to sedate patients in endoscopy units, and the necessary mechanisms to guarantee safe sedation should be established as well.

\section{ACKNOWLEDGMENTS}

Our thanks go to Dr. Enrique Domínguez Muñoz, Secretary of Sociedad Gallega de Patología Digestiva, for his comments on the manuscript.

\section{REFERENCES}

1. Wang T, Lin J, Waye JD. Worldwide use of sedation and analgesia for upper intestinal endoscopy. Sedation for upper GI endoscopy in
Taiwan. Gastrointest Endosc 1999; 50 (6): 888-91.

2. Froehlich F, Schwizer W, Thorens J, Kohler M, Gonvers JJ, Fried M. Conscious sedation for gastroscopy: patient tolerance and cardirespiratory parameters. Gastroenterology 1995; 108: 697-704.

3. U.K. Academy of Medical Royal Colleges and their Faculties. Implementing and ensuring safe sedation practice for healthcare procedures in adults. Report of a intercollegiate working party chaired by the Royal College of Anaesthetists. Available at: www.aomrc. org.uk. November 2001

4. Faigel DO, Baron TH, Goldstein JL, Hirota WK, Jacobson BC, Joahnson JF, et al. Guidelines for the use of deep sedation and general anaesthesia for GI endoscopy. Gastrointest Endosc 2002; 56: 613-7.

5. Guidelines for conscious sedation and during gastrointestinal endoscopy. Gastrointest Endosc 2003; 58 (3): 317-22.

6. Ciriza C, García L, Fernández A, Díez A, Delgado M, San Sebastián AI. Sedación en endoscopia digestiva. Análisis de la tolerancia y de las complicaciones. Rev Esp Enferm Dig 2001; 93: 587-92.

7. Quine MA, Bell GD, McCloy RF, Mathews HR. Prospective audit of upper gastrointestinal endoscopy in two regions of England: safety, staffing and sedation methods. Gut 1995; 36: 462-7.

8. Daneshmend TK, Bell GD, Logan RFA. Sedation for upper gastrointestinal endoscopy: results of a nationwide survey. Gut 1991; 32: 12-5.

9. Fasoli R, Repaci G, Comin U, Minoli G; Italian Association of Hospital Gastroenterologists. A multi-centre North Italian prospective survey on some quality parameters in lower gastrointestinal endoscopy. Dig Liver Dis 2002; 34 (12): 833-41.

10. Mulcahy HE, Hennessy E, Connor P, Rhodes B, Patchett SE, Farthing MJG, et al. Changing patterns of sedation use for routine out-patient diagnostic gastroscopy between 1989 and 1998. Aliment Pharmacol Ther 2001; 15: 217-20.

11. Campo R, Brullet E, Junquera F, Puig-Divi V, Vergara M, Montserrat A, et al. Sedación y anestesia en endoscopia digestiva. Resultados de una encuesta hospitalaria en Cataluña. Gastroenterol Hepatol 2004; 27 (3): 205.

12. Mokhashi MS, Hawes RH. Struggling toward easier endoscopy. Gastrointest Endosc 1998; 48: 432-40.

13. Council on Scientific Affairs, American Medical Association. The use of pulse oximetry during conscious sedation. JAMA 1993; 270: 1463-8.

14. Bell GD, Bown S, Morden A, Coady T, Logan RF. Prevention of hypoxaemia during upper gastrointestinal endoscopy by means of oxygen via nasal cannulae. Lancet 1987; 1: 1022-4.

15. Abraham N, Barkun A, LaRocque M, Fallone C, Mayrand S, Baffis $\mathrm{V}$, et al. Prediciting which patients can undergo upper endoscopy comfortably without conscious sedation. Gastrointest Endosc 2002; 56 (2): 180-9.

16. Ladas SD. Factors predicting the possibility of conducting colonoscopy without sedation. Endoscopy 2000; 32 (9): 688-92.

17. Cataldo PA. Colonoscoy without sedation: a viable alternative. Dis Colon Rectum 1996; 39: 257-61.

18. Ristikankare M, Hartikainen J, Heikkinen M, Jantuinen E, Julkunen R. Is routinely given conscious sedation of benefit during colonoscopy? Gastrointest Endosc 1999; 49 (5): 566-72.

19. Fisher NC, Bailey S, Gibson JA. A prospective, randomized controlled trial of sedation vs no sedation in outpatient diagnostic upper gastrointestinal endoscopy. Endoscopy 1998; 30: 21-4.

20. Cacho G, Dueñas C, Pérez de las Vacas J, Robledo P, Rosado JL. Viablidad de la colonoscopia sin analgesia y sedación consciente. Gastroenterol Hepatol 2000; 23 (9): 407-11. 


\title{
Sedación en las Unidades de Endoscopia de Galicia. Resultados de la encuesta de la Sociedad Gallega de Patología Digestiva
}

\author{
J. Cubiella Fernández, A. Lancho Seco, A. Echarri Piudo, J. L. Ulla Rocha, J. Fernández Seara en \\ representación de la Sociedad Gallega de Patología Digestiva
}

Servicio de Patología Digestiva. Complexo Hospitalario. Ourense

\begin{abstract}
RESUMEN
Objetivo: evaluar los medios materiales y humanos disponibles para la sedación y el modo habitual de manejarla en las unidades de endoscopia de Galicia.

Métodos: estudio prospectivo, descriptivo, basado en la realización, distribución y análisis de una encuesta sobre práctica clínica. Se solicitó información sobre las exploraciones realizadas, los medios disponibles para la sedación, el modo de controlarla y el nivel de sedación usado y deseable en cada exploración.

Resultados: la encuesta fue respondida por veinte unidades de endoscopia (trece de titularidad pública y once realizaban exploraciones de alta complejidad). El 80\% de las unidades estaban dotadas de pulsioximetría, el $42 \%$ de monitorización electrocardiográfica, el $40 \%$ de defibrilador y finalmente, el $45 \%$ de sala de recuperación. El fármaco más utilizado en las gastroscopias fue el midazolam (76\%) siendo la asociación midazolam-meperidina la sedación más utilizada en las colonoscopias (72\%) y la CPRE (60\%). El anestesista estaba disponible para determinadas exploraciones de forma habitual en el 15\%, y de forma excepcional en el 65\% de las unidades. El 35\% de los encuestados desearía tener un anestesista en la unidad a tiempo completo, el $25 \%$ sólo para exploraciones determinadas y el 35\% sólo para casos excepcionales. Finalmente, los encuestados consideran que es necesario algún grado de sedación en el $83 \%$ de las gastroscopias terapéuticas, en el $87 \%$ de las colonoscopias terapéuticas, en el 98\% de las CPRE, en el 95\% de las enteroscopias y en el $98 \%$ de las ecoendoscopias.

Conclusiones: aunque los endoscopistas consideran que los procedimientos endoscópicos deben ser sedados en una proporción elevada, en algunas unidades los medios disponibles para monitorizar con seguridad a los pacientes son insuficientes.
\end{abstract}

Palabras clave: Endoscopia gastrointestinal. Práctica profesional. Sedación consciente. Sedantes. Monitorización de drogas. Complicaciones.

\section{INTRODUCCIÓN}

La sedación en endoscopia digestiva es una parte fundamental en la práctica clínica habitual. Dependiendo del país, su uso de modo rutinario varía entre el 44 y el $72 \%$ (1). Si bien incrementa la tolerancia en determinadas exploraciones (2), también se asocia a un aumento de la morbilidad, especialmente debido a complicaciones cardiopulmonares (3-6). Estas complicaciones se incrementan en relación a la edad del paciente y a la patología aso- ciada $(4,6)$. Por este motivo, el endoscopista, no sólo debe manejar los fármacos, sino también debe disponer de los medios y conocimientos necesarios para monitorizar al paciente durante el procedimiento. Aunque los documentos de consenso y las guías clínicas publicadas recientemente especifican los requerimientos mínimos para la correcta sedación y la monitorización (3-5), las encuestas realizadas sobre la sedación en las unidades de endoscopia demuestran una gran variabilidad tanto en el modo de sedación como en los medios disponibles para la monitorización de los pacientes (7-9).

La Sociedad Gallega de Patología Digestiva (SGPD) es el órgano representativo de los especialistas de aparato digestivo en Galicia. Dentro de un programa para el conocimiento de la práctica de la especialidad en la comunidad gallega, se decidió evaluar las pautas de sedación en las unidades de endoscopia en función del tipo de exploración. El objetivo de este estudio fue conocer los medios disponibles, el modo de sedación habitual, y el grado y modo de sedación deseable por los endoscopistas en las unidades de endoscopia de Galicia.

\section{MATERIAL Y MÉTODOS}

\section{Diseño del estudio}

Estudio prospectivo, descriptivo, basado en la realización, distribución y análisis de una encuesta sobre práctica clínica.

\section{Elaboración de la encuesta}

La encuesta fue realizada por los autores en base a la revisión de las guías clínicas, los documentos de consenso y las encuestas sobre sedación disponibles en la literatura $(3,4,6-8)$. Una vez consensuado, se presentó a la junta directiva de la SGPD, aprobándose su envío a las unidades de endoscopia de nuestra comunidad. El cuestionario remitido se reproduce en la tabla I. 
Tabla I. Cuestionario sobre sedación elaborado por la SGPD y remitido a las unidades de endoscopia de los hospitales de Galicia. Se solicita a los facultativos participantes información sobre el volumen y tipo de endoscopias realizadas, los medios materiales y humanos disponibles, el modo habitual de sedación, el antecedente de complicaciones graves asociadas, el modo de adquirir los conocimientos para manejar la sedación y la pauta deseable en cada exploración.

SOCIEDAD GALLEGA DE PATOLOGÍA DIGESTIVA. CUESTIONARIO SOBRE SEDACIÓN

TIPO DE EXPLORACIONES REALIZADAS EN TU UNIDAD

Indica el número aproximado de exploraciones endoscópicas que se realizan en tu unidad anualmente

- Gastroscopias diagnósticas:

Gastroscopías terapéuticas:

- Sigmoidoscopias:

Colonoscopias diagnósticas:

- Colonoscopias terapéuticas:

CPRE:

- Enteroscopias:

Ecoendoscopias:

- Laparoscopias:

Indica el porcentaje aproximado de exploraciones que se realizan con sedación en tu unidad: A: 0-25\%, B: 25-50\%, C: 50-75\%, D: 75-100\%

- Gastroscopias diagnósticas

- Gastroscopias terapéuticas

- Sigmoidoscopias

- Colonoscopias diagnósticas

- Colonoscopias terapéuticas

- CPRE

- Enteroscopias

- Ecoendoscopias

\begin{tabular}{|c|c|c|}
\hline A & B & C \\
\hline A & B & C \\
\hline A & $B$ & C \\
\hline A & B & C \\
\hline A & B & C \\
\hline A & B & $C$ \\
\hline A & B & C \\
\hline A & $B$ & $C$ \\
\hline
\end{tabular}

PERSONAL Y MEDIOS DISPONIBLES

¿Cuáles son los medios disponibles para la sedación de los pacientes en tu unidad de endoscopias?

- Pulsioxímetro

- $\mathrm{O}_{2}$

- Defibrilador

Sí $\quad$ Nó $\quad$ No

No

Monitorización EKG y T. Art

Carro de paradas

Sala de recuperación

$\begin{array}{ll}\text { Sí } & \text { No } \\ \text { Sí } & \text { No } \\ \text { Sí } & \text { No }\end{array}$

¿Qué fármacos están disponibles?

- Diacepam oral/endovenoso

- Dolantina endovenosa

No

Midazolam oral/endovenoso

- Droperidol

- Atropina

Sí No

No

No

Sí Nín

Propofol

Anexate

Otros. Especificar

¿Cuáles son los fármacos más utilizados para sedación y analgesia?

- Gastroscopias diagnósticas:

Gastroscopias terapéuticas:

- Sigmoidoscopias:

- Colonoscopias terapéuticas:

Colonoscopias diagnósticas:

CPRE:

- Enteroscopias:

Ecoendoscopias:

¿Dispones de anestesista en tu unidad?

- Siempre disponible en la propia unidad

- Sólo para determinadas exploraciones (dilataciones, CPRE,...) pero de forma rutinaria

- Disponible en la unidad de forma inmediata cuando se le avisa pero con carácter excepcional

- No disponible de forma inmediata en la unidad: requiere programación

- No disponible de ninguna manera en la unidad: se debe acudir al quirófano

Si dispone de un anestesista en la Unidad, ¿es habitualmente el mismo, o cambia con frecuencia?

Si dispone de sala de recuperación:

- ¿Cuántos huecos tiene disponibles?

- ¿Quién controla a los pacientes?

¿Cuáles son los medios disponibles en su sala de recuperación?

- Pulsioxímetro

- $\mathrm{O}_{2}$

Sí No

- Defibrilador

No

No

Monitorización EKG y T. Art

Carro de paradas
No

No

No

No

No

En caso de no disponer de anestesista, ¿quién controla la sedación?
- El endoscopista
Sí
No
La enfermera

Sí

No 
Tabla I (continuación)

En caso de que sea el endoscopista el encargado de la sedación:

- ¿Dónde han adquirido los conocimientos de sedación consciente?

$\begin{array}{ll}\text { En cursos } & \text { De modo empírico } \\ \text { Rotación por anestesia } & \text { Durante la residencia } \\ \text { Otros } & \end{array}$

- ¿Recuerda haber sufrido alguna complicación grave derivada exclusivamente de la sedación en su unidad? No

Sí. ¿Cuáles?

¿Desearía tener un anestesista en la unidad?

- Sí, a tiempo completo para todas las exploraciones

- Sólo para casos excepcionales

Sólo para CPRE

Nunca

¿Qué tipo de sedación cree que es necesario en cada exploración (en porcentaje, de tal modo que sume el 100\%)?

\begin{tabular}{|l|l|l|l|}
\hline & No sedación & Sedación consciente & Sedación profunda \\
\hline Gastroscopias diagnósticas & & & \\
\hline Gastroscopias terapéuticas & & & \\
\hline Sigmoidoscopias & & & \\
\hline Colonoscopias diagnósticas & & & \\
\hline Colonoscopias terapéuticas & & & \\
\hline CPRE & & & \\
\hline Enteroscopias & & & \\
\hline Ecoendoscopias & & & \\
\hline
\end{tabular}

\section{Definiciones de sedación}

Se utilizaron las definiciones ya descritas en la literatura (3-5). Así, se definió la sedación consciente como una técnica en la cual el uso de una droga produce un estado de depresión del sistema nervioso central permitiendo la realización de una exploración, pero durante el cual se mantiene un contacto verbal con el paciente, y tanto la función respiratoria como la cardiovascular se mantienen. En contraposición se definió la sedación profunda como aquella sedación en la que el paciente no responde a estímulos verbales o dolorosos y puede no mantener la vía respiratoria abierta, requiriendo en habitualmente soporte respiratorio.

\section{Remisión de encuestas}

Se identificaron 29 unidades de endoscopia en hospitales en la comunidad autónoma de Galicia a partir del Catálogo de Hospitais Galicia 2000 editado por la Secretaria General del Servicio Gallego de Salud (SERGAS). De dichas unidades, 17 estaban ubicadas en hospitales públicos (14 en hospitales pertenecientes a la red del SERGAS, 2 en fundaciones públicas y una en hospital militar), 2 en hospitales privados concertados y 10 en hospitales privados. Se remitieron las encuestas por correo postal a los facultativos res- ponsables de las unidades en marzo de 2003. A los dos meses de ser enviadas, se contactó telefónicamente con aquellas unidades que no habían respondido y se les remitió nuevamente la encuesta por correo postal.

\section{Análisis estadístico}

Se realizó un análisis descriptivo de las respuestas. Para detectar diferencias entre los hospitales privados y públicos por una parte; y entre aquellos que realizaban exploraciones de alta complejidad (CPRE, enteroscopias, ecoendoscopias) y los que no por otra, se realizó un análisis univariante mediante la prueba exacta de Fischer para variables cualitativas y la U de Mann-Whitnney para variables cuantitativas. Se consideraron como estadísticamente significativas aquellas diferencias con $\mathrm{p}<0,05$. Los cálculos estadísticos se realizaron mediante el paquete estadístico SPSS 10.0.

\section{RESULTADOS}

\section{Características de las unidades}

Se recibieron respuestas a 20 de las encuestas remitidas (69\% de las unidades). Las unidades que respondie- 
ron eran 13 de titularidad pública (11 pertenecientes a la red del SERGAS, una fundación y un hospital militar) y 7 privadas (dos hospitales privados concertados). De las veinte unidades, once realizaban exploraciones complejas (CPRE 11, enteroscopia 6, ecoendoscopia 3). El volumen y el tipo de exploraciones se puede observar en la tabla II.

\section{Medios materiales y humanos disponibles}

Los medios materiales y los fármacos disponibles para la sedación en las unidades de endoscopias se pueden ver en la tabla III. El análisis univariante sólo identificó diferencias estadísticamente significativas $(\mathrm{p}=$ $0,026)$ en la disponibilidad de pulsioxímetro entre las unidades que realizaban exploraciones complejas $(11 / 11)$ y las que no las realizaban (5/9). Por otra parte, en las salas de recuperación, la mediana de camas fue de 2,5 (rango: 1-6), disponiendo ocho salas de pulsioxíme- tro y oxígeno, cuatro de monitorización de presión arterial y electrocardiograma, seis de carro de paradas y cinco de defibrilador. Por otra parte, a la pregunta sobre la disponibilidad de anestesista, ninguna unidad tenía anestesista permanentemente en la unidad. El 15\% disponían de anestesista sólo para exploraciones complejas, pero de forma rutinaria. El 30\% de las unidades tenían un anestesista de forma inmediata cuando se le avisa pero de forma excepcional. Un $45 \%$ no disponían de forma inmediata de un anestesista en la unidad, requiriendo programación. Finalmente, el 30\% de las unidades nunca tenían un anestesista en la unidad, debiendo acudir si era preciso al quirófano.

\section{Modo habitual de sedación}

El número de unidades que realizaban con sedación más del 50\% de las gastroscopias diagnósticas y terapéuticas fue $7 / 19$ y 11/18 respectivamente; de las colonosco-

Tabla II. Tipo de exploraciones realizadas por las unidades de endoscopia que respondieron a la encuesta y volumen de endoscopias expresado como mediana, mínimo y máximo

\begin{tabular}{lcccc}
\hline & $\mathbf{N}^{\circ}$ centros & Mediana exploraciones & Mínimo & Máximo \\
\hline Gastroscopias totales & 19 & 1.000 & 77 & 6.000 \\
Gastroscopias terapéuticas & 17 & 95 & 2 & 1.500 \\
Colonoscopias totales & 20 & 862 & 80 & 4.300 \\
Colonoscopias terapéuticas & 18 & 187,5 & 2 & 1.967 \\
CPRE & 11 & 106 & 3 & 450 \\
Enteroscopias & 6 & 20 & 137 & 100 \\
Ecoendoscopias & 3 & 170 & 80 & 260 \\
Total & 20 & 1.885 & & 11.110 \\
\hline
\end{tabular}

Tabla III. Medios materiales y fármacos disponibles para la sedación en las unidades.

\begin{tabular}{|c|c|c|c|c|c|}
\hline & \multirow[b]{2}{*}{ Global } & \multicolumn{2}{|c|}{ Titularidad del hospital } & \multicolumn{2}{|c|}{$\begin{array}{l}\text { Unidad que realiza } \\
\text { exploraciones complejas }\end{array}$} \\
\hline & & Pública & Privada & Sí & No \\
\hline Oxigenoterapia & $19 / 20(95 \%)$ & $13 / 13(100 \%)$ & $6 / 7(85,7 \%)$ & $11 / 11(100 \%)$ & $8 / 9(88,9 \%)$ \\
\hline Pulsioximetría & $16 / 20(80 \%)$ & $11 / 13(84,6 \%)$ & $5 / 7(71,4 \%)$ & $11 / 11(100 \%)^{\star}$ & $5 / 9(55,6 \%) *$ \\
\hline Monitorización TA + EKG & $8 / 19(42 \%)$ & $7 / 12(58,3 \%)$ & $1 / 7(14,3 \%)$ & $5 / 11(45,5 \%)$ & $3 / 8(37,5 \%)$ \\
\hline Carro de paradas & $16 / 20(80 \%)$ & $12 / 13(92,3 \%)$ & $4 / 7(57,1 \%)$ & $10 / 11(90,9 \%)$ & $6 / 9(66,7 \%)$ \\
\hline Defibrilador & $8 / 20(40 \%)$ & $6 / 13(46,2 \%)$ & $2 / 7(28,6 \%)$ & 4/11 (36,4\%) & $4 / 9(44,4 \%)$ \\
\hline Sala recuperación & $9 / 20(45 \%)$ & $5 / 13(38,5 \%)$ & $4 / 7(57,1 \%)$ & $7 / 11(63,6 \%)$ & $2 / 9(22,2 \%)$ \\
\hline \multicolumn{6}{|l|}{ Fármacos } \\
\hline Midazolam & $19 / 20(95 \%)$ & 13/13 (100\%) & $6 / 7(85,7 \%)$ & $11 / 11(100 \%)$ & $8 / 9(88,9 \%)$ \\
\hline Flumazenilo & $18 / 20(90 \%)$ & $12 / 13(92,3 \%)$ & $6 / 7(85,7 \%)$ & $11 / 11(100 \%)$ & $7 / 9(77,8 \%)$ \\
\hline Atropina & $18 / 20(90 \%)$ & $12 / 13(92,3 \%)$ & $6 / 7(85,7 \%)$ & $10 / 11(90,9 \%)$ & $8 / 9(88,9 \%)$ \\
\hline Meperidina & $18 / 20(90 \%)$ & $12 / 13(92,3 \%)$ & $6 / 7(85,7 \%)$ & $10 / 11(90,9 \%)$ & $8 / 9(88,9 \%)$ \\
\hline Diazepam & $15 / 20(75 \%)$ & $10 / 13(76,9 \%)$ & $5 / 7(71,4 \%)$ & $8 / 11(72,7 \%)$ & $7 / 9(77,8 \%)$ \\
\hline Propofol & $6 / 20(30 \%)$ & $3 / 13(23,1 \%)$ & $3 / 7(42,9 \%)$ & $2 / 11(18,2 \%)$ & $4 / 9(44,4 \%)$ \\
\hline Droperidol & $4 / 20(20 \%)$ & $4 / 13(30,8 \%)$ & $0 / 7(0 \%)$ & $4 / 11(36,4 \%)$ & $0 / 9(0 \%)$ \\
\hline
\end{tabular}

Se desglosan los resultados en función de la titularidad de los hospitales y de la realización de exploraciones de alta complejidad por parte de las unidades. Los resultados se expresan en números absolutos y porcentajes. Se identifican con asterisco aquellas diferencias estadísticamente significativas 
pias diagnósticas y terapéuticas fue 11/20 y 14/19 respectivamente; de las CPRE fue 11/11; de las enteroscopias fue $5 / 6 \mathrm{y}$, finalmente de las ecoendoscopias fue $2 / 3$. Por otra parte, si bien el midazolam fue el fármaco más utilizado para la sedación en las gastroscopias, tanto diagnósticas como terapéuticas, y en las enteroscopias, la asociación midazolam más meperidina fue el modo más habitual de sedación en las colonoscopias y las CPRE (Fig. 1). En caso de no disponer de anestesista, la sedación era controlada en el $44,4 \%$ de las unidades por el endoscopista, y en el 55,5\% por el endoscopista y el personal de enfermería. En la sala de recuperación, los pacientes son controlados por la enfermera en el 55,6\%, por el endoscopista en el 11,1\%, por ambos en el 22,2\%, y finalmente no son controlados en el $11,1 \%$ de las unidades de endoscopia. No hubo diferencias estadísticamente significativas en ninguna de las variables previamente comentadas

Respecto al modo de adquirir los conocimientos para el uso de los fármacos y su monitorización, se adquirieron de forma empírica en el $31 \%$ de los casos, durante la residencia en el $68 \%$, mediante cursos en el $12 \%$ y de otros modos en el 12\%. Por otra parte, el 33\% (6/18) de las unidades recuerdan haber tenido alguna complicación grave asociada a la sedación: depresión respiratoria en 2 de las unidades, parada respiratoria en 2 de las unidades y crisis convulsiva generalizada en 1 de las unidades.

\section{Nivel de sedación deseable}

A la pregunta sobre la necesidad de un anestesista en la unidad, el 35\% desearían un anestesista a tiempo completo para todas las exploraciones, el 25\% sólo para determinadas exploraciones, el $35 \%$ sólo para casos excepcionales, y finalmente, el $5 \%$ no desearían tener un anestesista. Finalmente, los facultativos consideraron que requerían algún grado de sedación, expresado en media \pm desviación estándar (DE), el 53,5\% (DE \pm $30,9 \%$ ) de las gastroscopias diagnósticas, el $83 \%$ (DE \pm $16,1 \%)$ de las terapéuticas, el 80,3\% (DE $\pm 19 \%)$ de las colonoscopias diagnósticas, el $87 \%$ (DE $\pm 17,1 \%$ ) de las terapéuticas, el 98\% (DE $\pm 6,9 \%)$ de las CPRE, el 95\% $(\mathrm{DE} \pm 14,1 \%)$ de las enteroscopias y el $98 \%(\mathrm{DE} \pm$ $4,5 \%$ ) de las ecoendoscopias. Los resultados a esta pregunta desglosados en función del tipo de sedación (no sedación, sedación consciente, sedación profunda) se pueden ver en la figura 2. No se encontraron diferencias estadísticamente significativas respecto a la titularidad del centro o a la complejidad de las exploraciones realizadas por las unidades.

\section{DISCUSIÓN}

La encuesta de la SGPD demuestra que, aunque en las unidades de endoscopia de Galicia se considera que se debería sedar a la mayoría de pacientes, esta no es la práctica clínica habitual en determinadas exploraciones. Existen varias encuestas que han evaluado la situación de la sedación en las unidades de endoscopia en Europa (7-10). Recientemente, se ha publicado el resultado de una encuesta sobre los hábitos de sedación en Cataluña en forma de comunicación a congreso (11). La metodología de los estudios publicados previamente es variada: encuestas anónimas $(8,11)$, revisión retrospectiva de bases de datos (10) y valoración prospectiva del tipo de sedación $(7,9)$. Nuestro principal objetivo al desarrollar la encuesta era conocer los medios disponibles y la valoración subjetiva por parte de los endoscopistas de las necesidades de sedación. Ciertos aspectos de la práctica clínica, como el tipo de sedación utilizado en cada exploración, el tipo de fármacos utilizados y el número de complicaciones que requerieren un estudio prospectivo para su correcta valoración. No obstante, los resultados de esta encuesta reflejan la práctica clínica habitual y los requerimientos de sedación valorados por los profesionales en Galicia, independientemente de la titularidad del centro, del número de endoscopias realizadas y de la complejidad de las exploraciones.

Aunque se han publicado diversas guías clínicas y documentos de consenso con recomendaciones sobre los medios necesarios para la sedación y el tipo de sedación deseable en cada exploración (3-5), las encuestas publicadas observan una divergencia entre dichas recomendaciones y la práctica habitual. Por otra parte, más alla de la discusión sobre la necesidad y el grado de sedación deseable en cada tipo de exploración, está claro que es necesario un mínimo de medios y unos conocimientos básicos para el manejo de la sedación con seguridad durante los procesos endoscópicos. De hecho, la sedación se estima que es responsable de entre el 30 y el $50 \%$ de los costes laborales y en equipamiento en las gastroscopias diagnósticas (12).

La monitorización durante el procedimiento endoscópico permite detectar signos tempranos de complicaciones tales como cambios en la función respiratoria, el pulso y la tensión arterial y en la actividad eléctrica cardiaca. Aunque la monitorización mediante equipos electrónicos mejora la valoración del paciente, no debe en ningún caso sustituir al control clínico (5). Un pulsioxímetro mejora el control de la función respiratoria en pacientes bajo sedación y analgesia $(13,14)$. Así mismo, la administración de oxígeno suplementario antes y durante la endoscopia disminuye la magnitud de la desaturación (12). Por este motivo, se recomienda tanto la monitorización con pulsioximetría como la administración de oxígeno durante todas las endoscopias con sedación (5). En nuestra encuesta, aunque la inmensa mayoría de unidades disponían de oxígeno, un $20 \%$ no disponían de pulsioxímetro. Este dato concuerda con la encuesta realizada por Fasoli y cols. sobre parámetros de calidad en la colonoscopia en el norte de Italia. En dicha encuesta se observó que, aunque el 63,9\% de las explora- 
ciones se realizaban con sedación, sólo el 44,2\% de los pacientes eran monitorizados mediante pulsioximetría (9). Respecto a la monitorización electrocardiográfica se recomienda su uso sólo en aquellos pacientes con patología cardiorrespiratoria, con edad avanzada o en procedimientos prolongados (5). En nuestras unidades, dicha monitorización sólo estaba disponible en el $42 \%$ de las salas. En nuestra encuesta no se solicitó información sobre otras tecnologías para la monitorización actualmente en evaluación tales como la capnografía y la monitorización biespectral (5). Por otra parte, las unidades de endoscopia deben tener disponibles los medios necesarios para recuperar al paciente de forma inmediata en caso de complicaciones (4). En nuestra encuesta, se demuestra que existen deficiencias importantes especialmente en relación a la ausencia de defibriladores en la mayoría de las unidades. Así mismo, es llamativo que sólo el $45 \%$ de los encuestados dispone de sala de recuperación, con lo que la recuperación tras la sedación se debe realizar en la sala de endoscopia en la mayor parte de los casos.

Existen grandes discrepancias sobre la utilidad de la sedación en las exploraciones endoscópicas, especialmente en referencia a las endoscopias digestivas altas y colonoscopias diagnósticas. Aunque ambos procedimientos pueden realizarse sin sedación en la mayoría de los pacientes $(15,16)$, dichas exploraciones son bien toleradas únicamente en el $59 \%$ de las gastroscopias (15) y en el $61 \%$ de las colonoscopias diagnósticas (17). Existen pocos estudios randomizados que evalúen la utilidad de la sedación en este tipo de exploraciones (18-20). En dichos trabajos, la mejoría en la tolerancia a la exploración tras recibir premedicación es escasa con factores como una edad avanzada o una disminución de la sensibilidad faringea en las endoscopias digestivas altas (15); y el sexo masculino o una resección intestinal previa en la colonoscopia (16) se asocian a una mejor tolerancia del procedimiento sin sedación. Nuestra encuesta no fue diseñada para evaluar el porcentaje de exploraciones que se realizaban con sedación y por lo tanto, los resultados no son comparables a lo publicado en la literatura. Sin embargo, hay que resaltar que el 63,2 y el $45 \%$ de las unidades sedaban menos del $50 \%$ de las gastroscopias y las colonoscopias diagnósticas respectivamente. Como es lógico, el porcentaje de unidades que realizaban sin sedación más del $50 \%$ de las exploraciones terapéuticas o complejas disminuye ampliamente. Sin embargo, a la pregunta del grado deseable de sedación en cada exploración, llama la atención que la media de gastroscopias y colonoscopias diagnósticas que se cree necesario realizar con sedación consciente se sitúa en el 50 y $72 \%$ respectivamente. Así mismo se cree necesario realizar con sedación profunda un 3 y $8 \%$ de dichas exploraciones. Este porcentaje difiere notablemente de la práctica actual en nuestras unidades, probablemente en relación a las deficiencias detectadas en los medios para la monitorización y al incremento en los tiempos de exploración asociados a la sedación. En el estudio realizado por Campo y cols. en Cataluña recientemente, el $17 \%$ de las gastroscopias, el $61 \%$ de las colonoscopias y el $100 \%$ de las CPRE se realizaron con algún tipo de sedación (11). Estos resultados son equiparables a los obtenidos en nuestro estudio.

Las guías clínicas y los documentos de consenso recomiendan el uso de las benzodiacepinas, especialmente el midazolam, para la sedación consciente de las endoscopias $(2,3,5)$. Aunque los datos sobre el beneficio del uso combinado de benzodiacepinas y opioides, tales como la meperidina, son contradictorios en la literatura, su uso está ampliamente extendido (7). En nuestra encuesta se observó que la monoterapia con midazolam era la pauta preferida para la sedación en endoscopias digestivas altas, siendo la combinación midazolam más meperidina la preferida para las colonoscopias y CPRE. Por otra parte, para poder realizar la sedación con seguridad es necesario tener fármacos que puedan revertir con prontitud los efectos sobre el sistema nervioso central. En nuestra encuesta, las unidades de endoscopia disponen de antagonistas de las benzodiacepinas en un elevado porcentaje.

En algunas exploraciones prolongadas y complejas, los pacientes se benefician de sedación mediante fármacos como propofol para inducir una sedación profunda (4). La sedación profunda se ha demostrado superior en endoscopias complejas, tales como la CPRE, a la sedación consciente. Sin embargo, la sedación profunda en la endoscopia rutinaria genera un escaso beneficio sobre la sedación habitual (19). Este tipo de sedación requiere una monitorización intensiva por personal cualificado, que en caso de riesgos asociados elevados debe ser controlada por un anestesista (5). En nuestra encuesta, el propofol es utilizado en el $6 \%$ de las gatroscopias y las colonoscopias terapéuticas y en el 10\% de las CPRE. Por otra parte, aunque la disponibilidad de anestesistas para monitorización y control de la sedación en las unidades de endoscopia es elevada, ninguna disponía de anestesista de forma permanente. No obstante, en el $35 \%$ de las encuestas se respondió que se desearía disponer de un anestesista permanentemente en la unidad. En los resultados publicados en forma de resumen por Campo y cols., el anestesista participó en la sedación en el $7 \%$ de las gastroscopias, en el 25\% de las colonoscopias y en el $38 \%$ de las CPRE (11), lo cual sugiere pautas de sedación muy similares a las documentadas en Galicia.

El facultativo encargado de la inducción de la sedación debe tener una formación específica que le permita manejar con seguridad al paciente durante el procedimiento. Debe conocer las dosis y los efectos adversos de los fármacos; el modo de revertir su efecto y el manejo de los medios para la monitorización. Asimismo, debe ser capaz de realizar las maniobras de resucitación cardiopulmonar avanzada con seguridad. En nuestra encuesta, la mayoría de los endoscopistas han obtenido sus conocimientos durante la residencia o de forma em- 
pírica, siendo escasos los que han realizado cursos específicos sobre técnicas de sedación. Es necesario, por tanto, que los endoscopistas reciban una formación específica en técnicas de sedación durante su formación y que estos conocimientos se actualicen posteriormente de forma periódica.

En conclusión, aunque las unidades de endoscopia en Galicia están bien dotadas respecto a fármacos, existen deficiencias notables en cuanto al equipamiento necesario para la monitorización del paciente. Así mismo, el porcentaje de unidades que sedan habitualmente ciertas exploraciones es bajo. Sin embargo, los endoscopistas consideran que los pacientes deberían ser sedados durante las endoscopias en un porcentaje más elevado del que se realiza hasta el momento actual. Es necesario un estu- dio prospectivo a nivel nacional que evalúe los medios disponibles para la sedación y la práctica clínica habitual en nuestro país. Así mismo se requiere establecer las condiciones mínimas para sedar a los pacientes en las unidades de endoscopia, así como los mecanismos necesarios para asegurar que estas se cumplan en las unidades de endoscopia.

\section{AGRADECIMIENTOS}

Al Dr. Enrique Domínguez Muñoz, en calidad de secretario de la Sociedad Gallega de Patología Digestiva, por sus comentarios al manuscrito. 